\title{
Edward Meryon (1809-1880) and muscular dystrophy
}

\author{
Alan E H Emery, Marcia L H Emery
}

\begin{abstract}
Edward Meryon was an English physician of Huguenot stock. He studied medicine at University College, London, and his chief appointments were at St Thomas's Hospital and the London Infirmary for Epilepsy and Paralysis. In a communication to the Royal Medical and Chirurgical Society in December 1851, which was published in the Transactions of the Society the following year, he described in detail eight boys in three families with a disease later to be associated with the name of Duchenne. He was particularly impressed by the predilection for males and its familial nature. He appears to have been the first physician to make a systematic study of the disorder some years before Duchenne.

(f Med Genet 1993;30:506-11)
\end{abstract}

In his seminal publications ${ }^{12}$ of 1861 and 1868 Guillaume Benjamin Amand Duchenne described in considerable detail the disease which was later to be associated with his name. This $\mathrm{X}$ linked disorder is characterised by progressive muscle wasting and weakness, mainly affecting the proximal musculature. It begins in early childhood and leads to death usually in the late teens or early twenties. Pseudohypertrophy of the calf muscles is invariably present in the early stages and hence the once used appellation 'pseudohypertrophic muscular dystrophy'. The gene locus is at $\mathrm{Xp} 21$ and the basic defect is a deficiency of muscle dystrophin, a cytoskeletal protein, though the details of pathogenesis are not yet clear. There remains no effective treatment.

However, although the first detailed clinical description and muscle histology have been attributed to Duchenne, in fact an English physician, Edward Meryon, appears to have described the disorder some 10 years earlier and to have been the first to publish the details in English. Although there had been previous reports of occasional patients with what would now be considered Duchenne muscular dystrophy, Meryon can be credited with having made the first systematic study of the disorder.

Green College, Oxford and 1 Eton Terrace, Edinburgh EH4 1QE, UK.

A E H Emery

M L H Emery
Meryon's contribution

At a meeting of the Royal Medical and Chirurgical Society in December 1851 Meryon de- scribed eight affected boys in three families. Interestingly, the older of the two affected brothers in the second family had been presented by a Mr Partridge in 1847 to the Pathological Society of London (reported in the London Medical Gazette, Volume 5, p 944), examination of whose muscle at necropsy had shown widespread fatty degeneration. Meryon's cases were reported in full the following year in the Transactions of the Medical and Chirurgical Society. ${ }^{3}$

The clinical descriptions are detailed and agree closely with what we would now refer to as Duchenne muscular dystrophy: difficulty in walking from an early age and later climbing stairs, ambulation eventually being lost and death occurring in the teens. Spontaneous muscle twitchings (fasciculations) were not observed nor any 'symptoms of nervous disturbance'.

The first family with four affected brothers and six healthy sisters appears to have been a noted county family and had been seen previously by Sir Benjamin Brodie among others. In this family the oldest boy (the Hon Geo P, born 1834) died aged 16 and, on receiving notice of his death, Meryon writes:

"I proceeded, on Saturday, the 21st of December, accompanied with Mr Tatum, to Bournmouth, where we examined the body twenty-two hours after death."

and after carrying out a necropsy, most significantly he comments:

"... the spinal cord itself and the membranes were perfectly sound and natural in appearance."

and later:

"The chief structural change existed in the system of the voluntary muscles, which was throughout the entire body atrophied, soft, and almost bloodless; and, although the muscular fibres appeared to exist, yet were they not of that deep red colour as seen in the healthy and natural state." (p 76)

Furthermore, microscopic examination of muscle showed:

“. . . the striped elementary primitive fibres were found to be completely destroyed, the sarcous element being diffused, and in many places converted into oil globules and granular matter, whilst the sarcolemma or tunic of the elementary fibre was broken down and destroyed." (p 76)

This last point is of singular interest now that the primary defect has been shown to reside in the muscle cytoskeleton.

Meryon recognised, however, that loss of 
muscle tissue could also result from disease of the spinal cord, independent of injury, but in fact emphasises:

" . . . in the first case which I have related, the spinal cord and nerves connected with it were carefully examined, and not the slightest trace of disease was detected. The relative proportion of the grey matter to the white in the cord, the ganglionic cells of the former, and the tubular structure of the latter, as well as of the nerves and the white substance within the neurolemma wherever examined by the microscope, all bore evidence of the healthy condition of the nervous system ... the only structural change observed was that which presented itself in the muscular fibres, which were broken down, and converted into granular and fatty matter." (p 78)

Thereafter he refers to the condition as 'Granular Degeneration of the Voluntary Muscles'.

He was also much impressed by the familial nature of the disorder and the predilection for males. In the three families (sibships) in his 1851 presentation there were eight affected brothers and nine healthy sisters.

Meryon's other major contribution on the subject is a lengthy chapter entitled 'Paralysis from Granular Degeneration of the Voluntary Muscles' in his monograph (fig 1) Practical and pathological researches on the various forms of paralysis published in $1864 .{ }^{4} \mathrm{Here}$, in addition to two families from his earlier publication, he also includes a further family of four affected sons of three sisters, a seemingly sporadic case, and an affected brother and sister aged 12 and 14 respectively. (Of the 13 cases originally described by Duchenne, two were also young girls. ${ }^{2}$ ) In total, it appears that Meryon studied six families, in five of which (seven sibships) only boys were affected (14 affected males with 13 unaffected sisters).

In his monograph Meryon is obviously aware of Duchenne's work subsequent to his own original (1851) presentation:

"In 1851 I communicated to the Royal Medical and Chirurgical Society a case of this description, together

\section{P RACT I CA L}

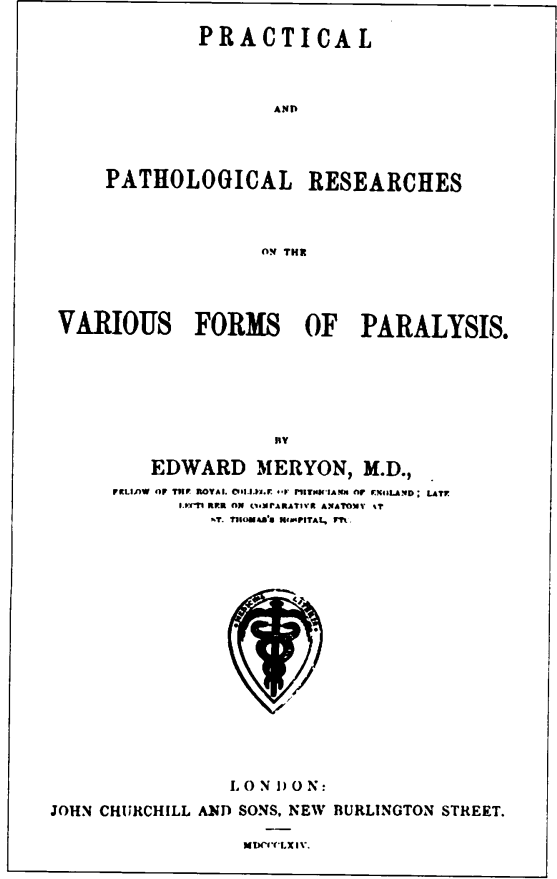

Figure 1 Title page of Meryon's monograph published in 1864 . with the result of a post-mortem examination, in which no lesion was found in any part of the nervous system. Previous to that time no account had been given of the precise nature of the disruption of muscular fibre which characterises this disease; and although I have hoped to see my opinion refuted by the demonstration of a nervous origin, it has been endorsed by most pathologists who have investigated the subject. It is not, as Duchenne has called it, a simple atrophy of muscles, but a breaking up of the sarcolemma of the elementary primitive fibres, and a segregation of the granules of which the sarcous matter is composed; therefore I still adhere to the term granular degeneration." (p 200)

And in stressing that the disease is limited to muscle and does not have a neurogenic origin, he compared the spinal cord from one of his patients with that of a control:

"On the day after the examination a youth of the same age (18) was kicked by a horse, and killed on the spot. My late friend Mr Avery, who was then surgeon to the Charing Cross Hospital, procured for me the spinal cord, by which I was enabled to compare that of my patient with one that was known to be perfectly healthy, and I may state that in form, size, firmness, colour, and appearance under the miscroscope, the two corresponded in every respect." (p 201)

He also enlisted collaborative evidence from others:

"My friend the Hon and Rev Lord Sidney Godolphin Osborne, an accomplished microscopist, has for many years taken a lively interest in these cases of granular degeneration of the voluntary muscles, and has spent much time in examining the different tissues obtained at the post-mortem investigation made by $\mathrm{Mr}$. Savory. In a letter to me he observes, 'I am in my own mind quite satisfied that the peculiar paralysis about which you write to me, affords no direct evidence of lesion in any structure but the muscular.'" (p 210)

\section{and later:}

"Notwithstanding an earnest desire to find a central nervous cause, I am induced to believe in an idiopathic disease of the muscles, dependent, perhaps, on defective nutrition, just as there is an idiopathic disease of the bones, dependent on the same cause. And I consider that the consequent degeneration of the muscles is characterized by a breaking up of the amorphous membrane which envelopes the primitive fibres, and a dispersion of the contained granular matter; that the muscles affected lose their power, in direct proportion to the amount and progress of the degeneration; and that the disease is not apt to be accompanied with symptoms of nervous disturbance." (p 211)

In summary, Meryon seems to have been convinced that this was a specific disorder, characterised by progressive muscle wasting and weakness, beginning in early childhood and leading to premature death in the late teens, was not the result of any involvement of the spinal neurones but was essentially a disease of muscle, was frequently familial, and had a predilection for males. There is little doubt that he was describing the disease later to be referred to as Duchenne muscular dystrophy.

In his own studies published in $1868,{ }^{2}$ Duchenne refers on several occasions to Meryon's publication of 1852 but seems to be under the misapprehension that Meryon considered the disorder progressive muscular atrophy:

"Mais l'observateur distingué, M. Edw. Meryon, qui en a exposé la relation, les ayant évidemment confondus avec l'atrophie musculaire progressive, je dois me 
réserver d'en discuter le diagnostic différentiel, avant de les ranger ici parmi les cas de paralysie pseudohypertrophique précédents." (p 25)

Could this be why Meryon's work has been largely ignored? Duchenne proceeds later (p 428 onwards) to a detailed discussion of the differential diagnosis of "... atrophie musculaire graisseuse progressive de l'enfance et de la paralysie pseudo-hypertrophique", the former, but not the latter, being caused by a lesion in the spinal cord. Indeed an analysis of who may first have delineated progressive muscular atrophy could well form the basis for a separate study (see Duchenne, ${ }^{2}$ pp 432-3).

\section{Earlier descriptions of the disease}

With a disease which is relatively common, so characteristic and serious, and often affects more than one boy in a family, it seems likely that others before Meryon would have noted the disorder. In fact Pöch and Becker ${ }^{5}$ suggested that a relief painting on the wall of a tomb in Pharaonic Egypt, dating from the 18th Dynasty of the New Kingdom (about 1500 BC), may represent muscular dystrophy. The subject however is the Queen (sic) of Punt who shows lordosis and in fact seems more likely to be simply a Nubian with steatopygia. ${ }^{6}$ More relevant is perhaps a drawing from a tomb at Beni Hasan (c 2800-2500 BC) which we located in the Ashmolean Museum, Oxford (Number 17 in Newberry ${ }^{7}$ ). Three figures are depicted. The first has bilateral club foot and the second is a boy with what might be muscular dystrophy. He has lost the normal arch of his feet, which is usually clear in Egyptian wall paintings as seen in the third figure. His calves also seem somewhat enlarged and he may have $\square$ Louis Merinian

Louis Mirian or Lewis Meryon (1677-1738)

Lewis Meryon

(1708-1751)

Lewis $M$.

(1739-1824)

John M

(1776-1857)

Edward M

(1809-1880)

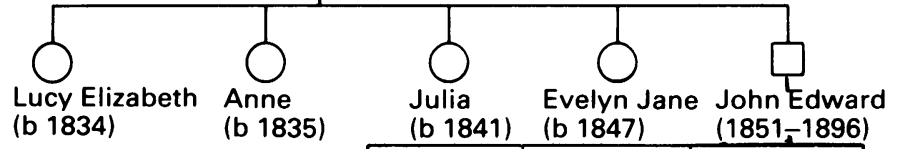

(b 1835)
Julia (b 1841) (b 1847)

some degree of (pseudo)hypertrophy of certain upper limb muscles.

This of course is all speculative and it was not until the 19th century that clear clinical descriptions of dystrophy appear. First among these was by the Edinburgh surgeon-anatomist Charles Bell (1774-1842) who is best remembered for having described paralysis of the facial nerve (Bell's palsy). In his The nervous system of the human body, published in $1830,{ }^{8}$ he describes (case 89) a young man of 18 with progressive muscle wasting and weakness which began around the age of 10 . Though there was no pathology to establish the diagnosis, the clinical description given by Bell would favour muscular dystrophy.

The first most clear and detailed clinical description, however, was given by the Neapolitan physician Professor Gaetano Conte, with the help of a Dr L Gioja, reported in the Annali Clinici dell'Ospedale degli Incurabili di Napoli in $1836 .{ }^{9}$ The original publication has now been reprinted and commented on by Nigro. ${ }^{10}$ Conte and Gioja ${ }^{9}$ described two brothers who apparently first manifested the disease at the age of 8 , had enlarged calves, and progressive muscle wasting and weakness which particularly affected the lower limbs. They subsequently developed contractures of the knees and hips. The older brother died of cardiac failure. In both boys sensory function and mentation were normal. Unfortunately there was no report of muscle pathology, though the clinical features would again be consistent with Duchenne muscular dystrophy.

A few years later, in 1847, Dr W J Little, a physician at the London Hospital, also reported two affected brothers aged 12 and 14. Both had been unable to walk from the age of 11 and the older died at 14 years. At necropsy, examination of the gastrocnemius and soleus muscles showed that the muscle tissue had been largely replaced by fat. These cases were reported in detail by Little in $1853 .{ }^{11}$

These early descriptions are all consistent with the diagnosis of Duchenne muscular dystrophy, but it seems clear that the first systematic and detailed study of the disorder must be attributed to Edward Meryon.

\section{Edward Meryon: the man and his family}

The Huguenots were Protestant refugees from the Catholic regime in France, following the revocation of the Edict of Nantes in $1685,{ }^{12}$ from whom Edward Meryon was descended, through a Louis Merinian, who arrived in Rye, Sussex, around this time. After a generation or so the family name had become established as Meryon (fig 2).

Edward Meryon's father (V·1) was a John Meryon (1776-1857), a distinguished member of Rye Society, having been admitted a Freeman of the town in 1798, Harbour Commissioner, and briefly, in 1825, Mayor, and with his brother in law owned a brewery in Rye. ${ }^{1314}$

Edward Meryon (fig 3) was born in Rye in 1809 but the exact date of birth is not known 
nor is anything known of his early life. Around 1827 he entered University College, London, to study medicine and also, according to his own record, the École de Médecine, Paris, though we have so far been unable to confirm this. He qualified MRCS in 1831. The main events of his subsequent career are summarised in the table. He died in London in 1880 and is buried in Brompton Cemetery.

He practised mainly as a physician but may also have been an accoucheur because, according to family legend, he was invited to attend the confinement in 1856 of the Empress Eugenie, the wife of the Emperor Napoleon III. He may, however, have only been instrumental in procuring the services of an English governess or nurse (Duff, ${ }^{15} \mathrm{p}$ 126). In any event, he was presented with an elaborately decorated snuff
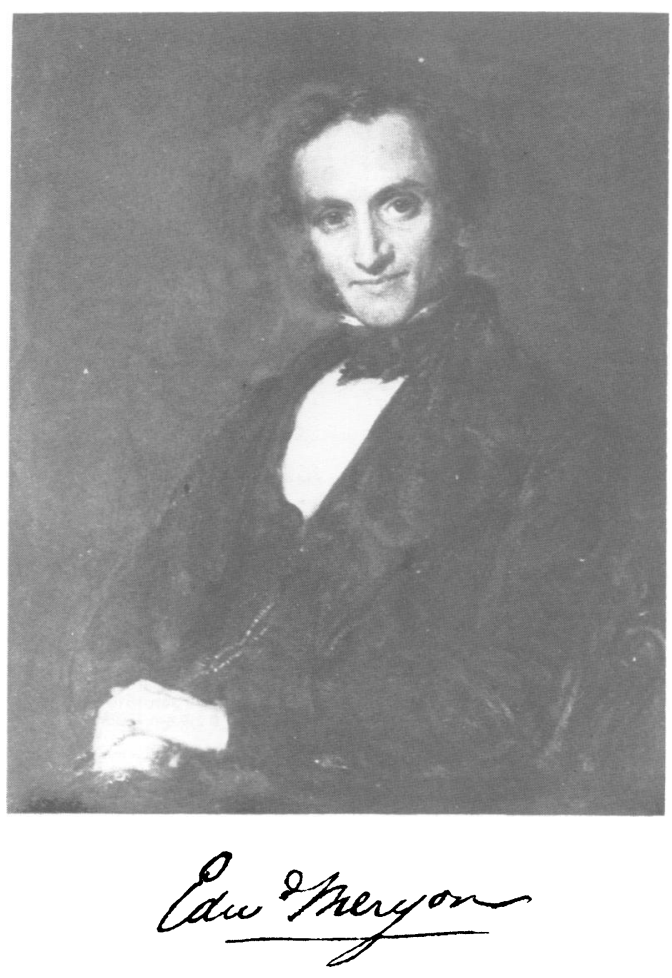

Figure 3 Dr Edward Meryon (by fohn Linnell (1792-1882), private collection).

\section{Edward Meryon's life.}

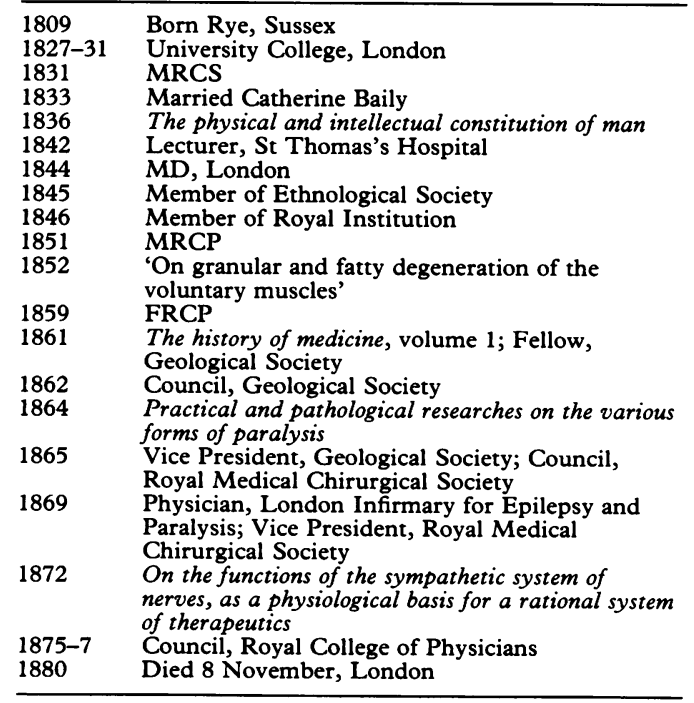

box by the Emperor, which is still in the family's possession.

In 1833 he married Catherine Baily (18111897) from the village of Falkingham in Lincolnshire. The couple had four daughters and a son, John Edward (1851-1896). The latter married Isobella Chalmers (1853-1940), a descendant of the famed Scottish theologian Thomas Chalmers. And John Edward's son (VIII-1) married Marjorie Wedgwood, a member of another notable family. It appears that in the present generation the youngest Meryon male is descended from this couple, and has been christened Edward Meryon! The Meryon line has also continued to the present day through VIII.4.

Edward Meryon's father John (V.1) had a distinguished younger brother, Charles Lewis Meryon (1783-1877), who led a fascinating and eventful life. ${ }^{16} \mathrm{He}$ studied at St John's College, Oxford, became a physician and later a confidant and companion of the eccentric traveller Lady Hester Stanhope ${ }^{17}$ about whom he wrote two three volume works. ${ }^{1819} \mathrm{By}$ a French ballet dancer, Narcisse Chaspoux, he had an illegimate son who was also named Charles Meryon (1821-1867). The latter, after being an officer in the French navy, became an accomplished and well known engraver and etcher. He developed schizophrenia and was known to, and documented by, Dr Gachet who also cared for Vincent Van Gogh..$^{20} \mathrm{~A}$ full and detailed pedigree of the family is reproduced as an appendix.

From many different points of view, the Meryon family is indeed illustrious. The family crest is a busy bee, and the family motto 'Si non hodie - quando?' (If not today when?) which, in the circumstances of Edward Meryon's neglect in the history of muscular dystrophy, would seem particularly appropriate.

We are very grateful to the following for much valuable help and information about Edward Meryon and his family: Ms A Armstrong (University College), Mr Andrew Baster (St Thomas's Hospital), Mrs Mary Bayliss (Hon Sec, Huguenot Society), Miss Alma Fabes (of Rye), Mr G Palmer (Rye Local History Society), the staff of the Rye Library and the East Sussex County Record Office, and particularly members of the family, as well as Dr Trevor Hughes for his help and encouragement and Mrs Isobel Black for her secretarial assistance.

1 Duchenne GBA. De l'electrisation localisée et son application à la pathologie et à la thérapeutique. 2nd ed. Paris: Baillière et fils, 1861 .

2 Duchenne GBA. Recherches sur la paralysie musculaire pseudohypertrophique ou paralysie myo-sclérosique. Arch Gen Med 1868;11:5-25, 179-209, 305-21, 421-43, 552-88.

3 Meryon E. On granular and fatty degeneration of the voluntary muscles. Med Chir Trans 1852;35:73-84.

4 Meryon E. Practical and pathological researches on the various forms of paralysis. London: Churchill, 1864 .

5 Pöch H, Becker PE. Eine Muskeldystrophie auf einem altägyptischen Relief. Nervenarzt 1955;26:528-30.

6 Riad N. La médecine au temps des Pharaons. Paris: Librairie Maloine, 1955:242.

7 Newberry PE. Beni Hasan. Part II. In: Griffith FL, ed. Archaeological survey of Egypt. London: Kegan Paul, Trench, Trübner \& Co, 1893

8 Bell C. The nervous system of the human body: as explained in a series of papers read before the Royal Society of London. Edinburgh: Adam \& Charles Black, 1830 
9 Conte G, Gioja L. Scrofola del sistema muscolare. Annali Clinici dell'Ospedale degli Incurabili di Napoli 1836;2:6679.

10 Nigro G. Conte or Duchenne? Cardiomyology 1986;5:3-30. 11 Little WJ. On the nature and treatment of the deformities of the human frame: being a course of lectures delivered at the Royal Orthopaedic Hospital in 1843. London: Longman, Brown, Green \& Longmans, 1853:14-16.

12 Boulenger J. The national history of France - the seventeenth century London: Heinemann, 1920.

13 Vidler LA. A new history of Rye. Hove: Combridges, 1934.

14 Fabes A, Gibson E. The Meryon story. Rye, Sussex (privately published), 1985 .
15 Duff D. Eugenie and Napoleon III. London: Collins, 1978 6 Hill B. Charles Meryon, MD, FRCP. Practitione 1977;218:721-30

17 Hamel F. Lady Hester Lucy Stanhope: a new light on her life and love affairs. London: Cassell \& $\mathrm{Co}, 1913$.

18 Meryon CL. Memoirs of the Lady Hester Stanhope. 3 volumes. London: Henry Colburn, 1845.

19 Meryon CL. Travels of Lady Hester Stanhope. 3 volumes. London: Henry Colburn, 1846.

20 Lundström LI. Charles Meryon (1821-67), peintre-graveur schizophrène. Acta Psychiatr Scand 1964;40(suppl 180):159-65.
MERYON PEDIGREE

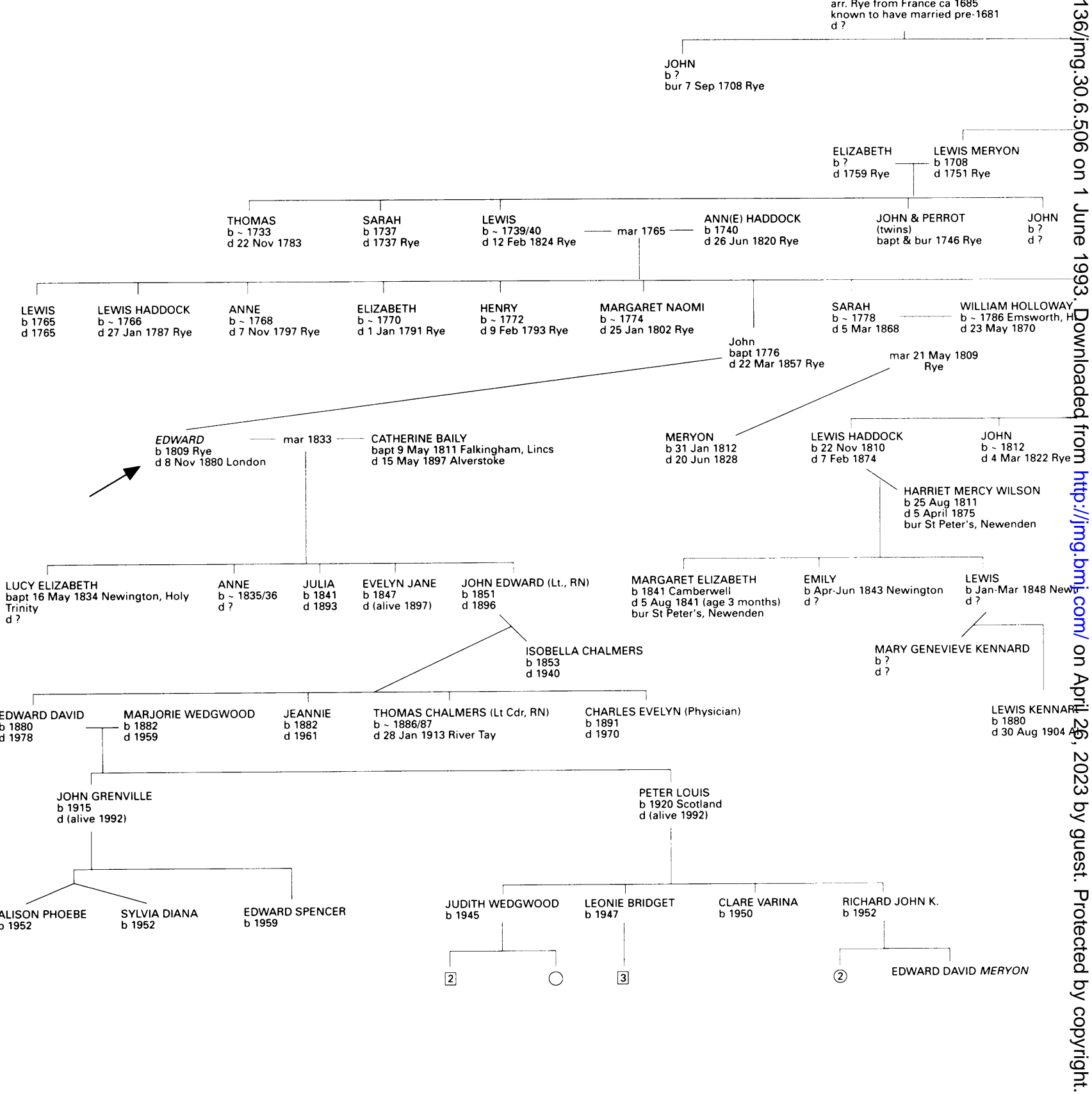



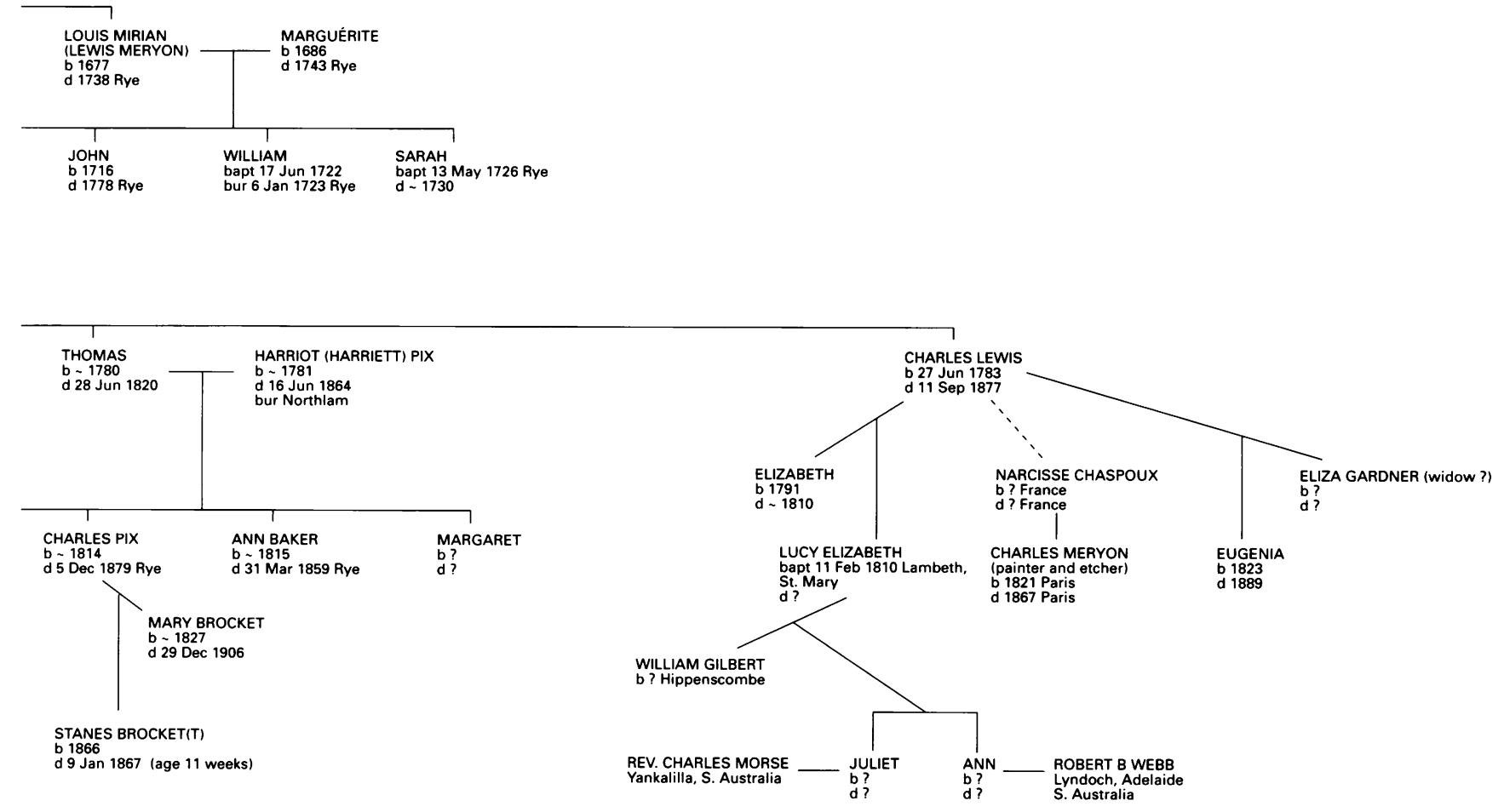